\title{
Sensory Evaluation of Guava Cheese Prepared from Different Varieties
}

\author{
Rashmi Shukla $^{1 *}$, Y.K. Shukla ${ }^{1}$ and Smita Pathak ${ }^{2}$ \\ ${ }^{1}$ Krishi Vigyan Kendra, B.M. College of Agriculture, Khandwa (M.P.), India \\ ${ }^{2}$ Government Home Science College, Jabalpur (M.P.), India \\ *Corresponding author
}

\begin{tabular}{|l|}
\hline Ke y w o r d s \\
Guava cheese, \\
Additive, \\
Appearance, \\
Acceptability, \\
Texture
\end{tabular}

\section{A B S T R A C T}

Guava (Psidium guajava L.) is considered as one of the exquisite, nutritionally valuable and high remunerative crop. It is an important component of human dietary system. Guava cheese is gaining importance in International market due to its high nutritive value and better self-life and taste changing the consumer taste from regular product like Jelly, paste and puree to modern product. In the present investigation guava cheese was prepared from different varieties viz. Lucknow-49, Allahabad safeda and Apple guava with addition of milk powder and without any additive. The sensory evaluation was performed on 9 point hedonic scale on ISI (1971). The highest value of prepared guava cheese was recorded in colour/appearance (7.90) under Apple guava while addition of milk powder it was (6.90) as compared to no addition of any additive (6.94). In taste L- 49 and Apple guava was found same value (8.30) while cheese prepared from without additive it will be higher value (8.30) as compared to addition of milk powder (7.93). In flavor it was high (8.0) in Apple guava as compared to other varieties while addition of milk power it's value decreased (7.31) while without addition it was (8.13). In texture it was found highest (7.52) in L-49 as compared to others while without addition of milk powder it was better (7.61) as compared to addition of milk powder (6.80). Over all acceptability (7.81) Apple guava variety was found better and without adding any additives it was found better value (7.93) as compared to addition of milk powder.

\section{Introduction}

Guava (Psidium guajava L.) is a most important fruit of the world. It has been cultivated in India, since early $17^{\text {th }}$ century and gradually became a crop of commercial significance.

In terms of area and production, it is the fourth most important fruit crop of India after mango, banana and citrus. At present, it occupies nearly 1.12 lakh hectare of land with production of 12.04 lakh tons and productivity 10.77 tons fruits / hectare / year in India (DAC, 2007).

The guava varieties which are mainly grown in central India are Allahabad Safeda, Lucknow-49 and Apple guava. These varieties have immense commercial importance due to yellowish white colour, sweet taste with mild flavour pulp quality. Guava is considered as one of the exquisite, nutritionally valuable and high remunerative crop. It is an important 
component of human dietary system. The guava fruit is an excellent source of ascorbic acid $(260 \mathrm{mg} / 100 \mathrm{~g})$, pectin (0.52 to $2.0 \%)$, phosphorus (23-27 $\mathrm{mg} / 100 \mathrm{~g})$ and calcium $(14-30 \mathrm{mg} / 100 \mathrm{~g})$. The fresh fruit of guava also provides vitamins like niacin, pantothenic acid, thiamin, riboflavin and vitamin A (Bose et al., 1999). Immature fruits of guava are used in treatment of gastroenteritis, diarrhea, dysentery, blood pressure and cardiovascular diseases (Hisn- Chun Chen, 2007).

Processing is a very authentic way of value addition of fruit crops to produces food products for generating additional source of income and employment. Processing make the products free from unwanted fractions and transform it in to more useful form and thereby increasing the shelf life over fresh products. The demand for the processed food products is increased enormously in the country.

Therefore, it is an urgent need to pay more attention on the processing of guava fruits as well as the production of acceptable products, so that the growers may get remunerative prices and consumers get opportunity to enjoy the test of guava in the form of the food products. Presently guava varieties are utilized for production of jam, jelly, pulp, puree, toffee, leather, juice, baby foods, beverage base, syrup and wine (Lal et al., 1998; Jain and Asati, 2004). Apart from above products, guava pulp is also being used for preparation of new product like cheese.

Consumer taste towards the consumption of regular jam, jelly, paste and puree is changing with modern products. The fruit cheese or cheese like product is gaining importance in the international market. In the last couple of years several attempts have been made to develop the technology for production of guava cheese by utilizing the local varieties but the product quality was not consistent.

\section{Materials and Methods}

Fresh and ripened fruits of guava cultivars viz., Lucknow-49, Allahabad safeda, and Apple guava were collected from the guava orchards of Fruit Research Farm, Imalia, J.N. Krishi Vishwa Vidyalaya, and Jabalpur (M.P.) for preparation of the cheese.

The cheese was prepared from the fruits of each variety using with and without use of milk powder. These treatments were replicated five times in order to minimize the error.

The recorded data were tabulated and statistically analyzed.

\section{Treatments}

6 (3 varieties $x 2$ formulation of cheese)

Guava varieties

Lucknow-49 - $\mathrm{V}_{1}$

Allahabad Safeda $-\mathrm{V}_{2}$

Apple guava - $\mathrm{V}_{3}$

Formulation of cheese

Without milk powder - $\mathrm{W}_{0}$

With milk powder - $\mathrm{W}_{1}$

Replications - Five

\section{Preparation of guava cheese (R.P.} Shrivastav and Sanjeev Kumar, 2003)

\section{Sorting of fruits}

Well ripened healthy and fresh guava fruits of each variety were selected for the study. Over ripened, unripened and rotted fruits were discarded.

\section{Washing of fruits}

Before processing, the fruits were thoroughly washed with tap water to remove the dust, and other undesirable foreign materials adhering on the surface of fruits. 


\section{Cutting of fruits}

The cleaned fresh fruits were cut into slices of about $1 \mathrm{~cm}$ thickness with the help of stainless steel knife for each treatment.

\section{Boiling of fruit slices}

The slices of fruits for each treatment were boiled with water continuously till the period, when all slices became completely soft. After this, the boiled slices of fruits of each variety were allowed to cool under natural conditions.

\section{Mashing and sieving of fruit slices}

The soft fruit slices were properly mashed manually to facilitate quick and easy method of sieving. After completing the mashing of slices, pulps were used for sieving.

Addition of sugar, butter, citric acid and milk powder

After proper mashing and sieving of fruit slices, the desired quantity of sugar, butter and citric acid were added for preparation of cheese.

In other formulation of guava cheese was prepared with milk powder in addition to other ingredients as per treatments.

\section{Determination of end point for cheese preparation}

After addition of sugar, butter, citric acid as well as milk powder in fruit pulp as per treatments, the mixture of pulp was allowed for cooking in a metallic pan by continuous stirring till the period when mixtures became sufficiently thick and started to leave the sides of the pan.

This was the end point of cheese preparation, these, the pan were removed from the fire.

\section{Setting of guava cheese}

The cooked guava cheese after removal from fire were spread over butter coated tray of 20 $\mathrm{cm} \times 20 \mathrm{~cm}$ size, as per the treatments wise. One centimeter thickness of the layer of guava cheese was uniformly in each tray and then allowed to setting for 3 hours.

\section{Sensory evaluation of guava cheese}

The prepared guava cheese was put up before a panel of experts for sensory evaluation on a 9 point hedonic scale based on the various quality attributes like colour, taste, flavour, texture and over all acceptability using the method described by Amerine et al., (1965).

In the hedonic rating test panelist were asked to rate the acceptability of the product on a scale, usually of 9 points ranging from 'like extremely' to 'dislike extremely'

\section{Results and Discussion}

The sensory evaluation of colour of cheese was undertaken after it preparation. The opinion was marked on the nine Hedonic rating scales numerically. The prepared cheese from the variety Apple guava marked higher rank (7.90) in relation to the colour of cheese. Whereas, the cheese prepared from variety Allahabad safeda ranked 6.67 and comparatively proved significant inferior to others. The milk powder markedly reduced the appearance of cheese over without milk powder. The maximum marks was obtained in hedonic scale was 7.83 under without milk powder which was significantly superior to be with milk powder (6.94).Interaction of variety and milk powder found to be significant and data showed that all the varieties without milk powder perform better in relation to contribute the colour whereas addition of milk powder markedly reduced the appearance of cheese. The maximum value of (8.50) was noted for 
variety Apple guava without milk powder whereas, the lowest rank (6.39) was observed in the treatment of Allahabad safeda with milk powder Table 1. Similar findings were noted by Aruna et al., (1999), Ahmad et al., (2000), Shukla et al., (2003), Mishra and Chopra (2006).The findings in relation to taste of cheese was recorded and presented in Table 2. The statistical analysis (Table) reveal that the guava varieties used for preparation of cheese had marked effect on taste of cheese. Guava variety Lucknow-49 and Apple guava showed similar taste and both of them proved significantly superior over Allahabad safeda.

The addition of milk powder as additive during preparation of cheese had negative effect on the taste of the cheese and showed lower values markedly (7.93) over cheese prepared without milk product (8.30). The interaction between varieties and value addition milk powder treatments was found to be no significant with respect of taste of prepared guava cheese. Similar findings were noted by Mishra and Chopra (2006) and Prasad and Mali (2006). Flavour of cheese was assessed by using nine point hedonic scale Table.

The sensory score of flavour (8.0) was noted under Apple guava and proved significantly superior over Lucknow-49 and Allahabad safeda. Though the variations between Lucknow-49 and Allahabad safeda were not significant. The milk powder significantly reduced the flavour score of the cheese. The recorded values on flavour were 8.13 and 7.31 under without milk powder and with milk powder cheese product, respectively.

The interaction of guava varieties and milk powder level was had non-significant. Similar finding are noted by Baramanray et al., (1996), Aruna et al., (1999) and Badrie et al., (2005). Statistical analysis of data shows that the texture score of the cheese changed significantly due to use of pulp of different guava varieties. The variety Lucknow-49 ranked first with the value of 7.52 and proved significantly superior over Allahabad safeda (7.05) and Apple guava (7.05). However the variation was no significant between Allahabad safeda and Apple guava table 3. The effect of levels of addition of milk powder on texture score of cheese was significantly higher mean score of texture was recorded for product without use of milk powder.

The interaction between variety and milk powder had significant effect on the texture score of the cheese. Among the varieties Lucknow-49 possessed higher value (8.55) over varieties used for preparation of cheese. However, varieties Allahabad safeda and Apple guava did not show any mark able difference for product of and without use of milk powder and recorded almost similar values of texture table 4 .

The overall acceptability of prepared cheese was recorded on the basis of assessment report by panelist the recorded opinions were tabulated and presented as under table 5.The statistical analysis showed that the variety of guava significantly changed the acceptability of the product. The prepared cheese from the Apple guava pulp found to be more acceptable and recorded the scale values of 7.81 followed by Lucknow- 49 with 7.78 scale values and both are significantly superior over to Allahabad safeda and showed no significant difference to each other. Results presented in Table clearly indicate that the guava cheese prepared without milk powder show higher overall acceptability as compared to product prepared with milk powder.

The combined effect of varieties and milk powder found to bring out the change in the acceptability of the product. Cheese from all the three varieties without milk powder proved to be better over with milk powder. 


\section{Flow chart of processing of Guava cheese}

Fresh washed fruits

Guava fruits cut into small pieces as per the varieties used<smiles>[AlH2]</smiles>

Put in a pressure cooker pan with water<smiles>[AlH2]</smiles>

Cooked for 10 minutes<smiles>[AlH]</smiles>

Remove from heat<smiles>[AlH2]</smiles>

Leave the cooker to cool down

Opened the cooker and take out the fruit pieces

Mesh nicely, strain to get the pulp, discarded the seeds etc.

Put the pulp in a vessel

Salt, sugar and butter to the pulp and milk powder as per the treatments

Cooked over low heat<smiles>[AlH2]</smiles>

Removed from heat when mixture starts leaving sides of pan<smiles>[AlH2]</smiles>

Add citric acid, and mix well

\section{Leave to cool}

$\downarrow$

Evenly distributed over butter coated tray and leave for 3 hours to set $\downarrow$

Storing in cool dry place as per the packaging materials

Nine Point Hedonic scale for sensory attributes

\begin{tabular}{|c|l|c|}
\hline S. No. & \multicolumn{1}{|c|}{ Characteristics } & Organoleptic score \\
\hline 1. & Liked extremely & 9 \\
\hline 2. & Liked very much & 8 \\
\hline 3. & Liked moderately & 7 \\
\hline 4. & Liked slightly & 6 \\
\hline 5. & Neither liked nor disliked & 5 \\
\hline 6. & Disliked slightly & 4 \\
\hline 7. & Disliked moderately & 3 \\
\hline 8. & Disliked very much & 2 \\
\hline 9. & Disliked extremely & 1 \\
\hline
\end{tabular}



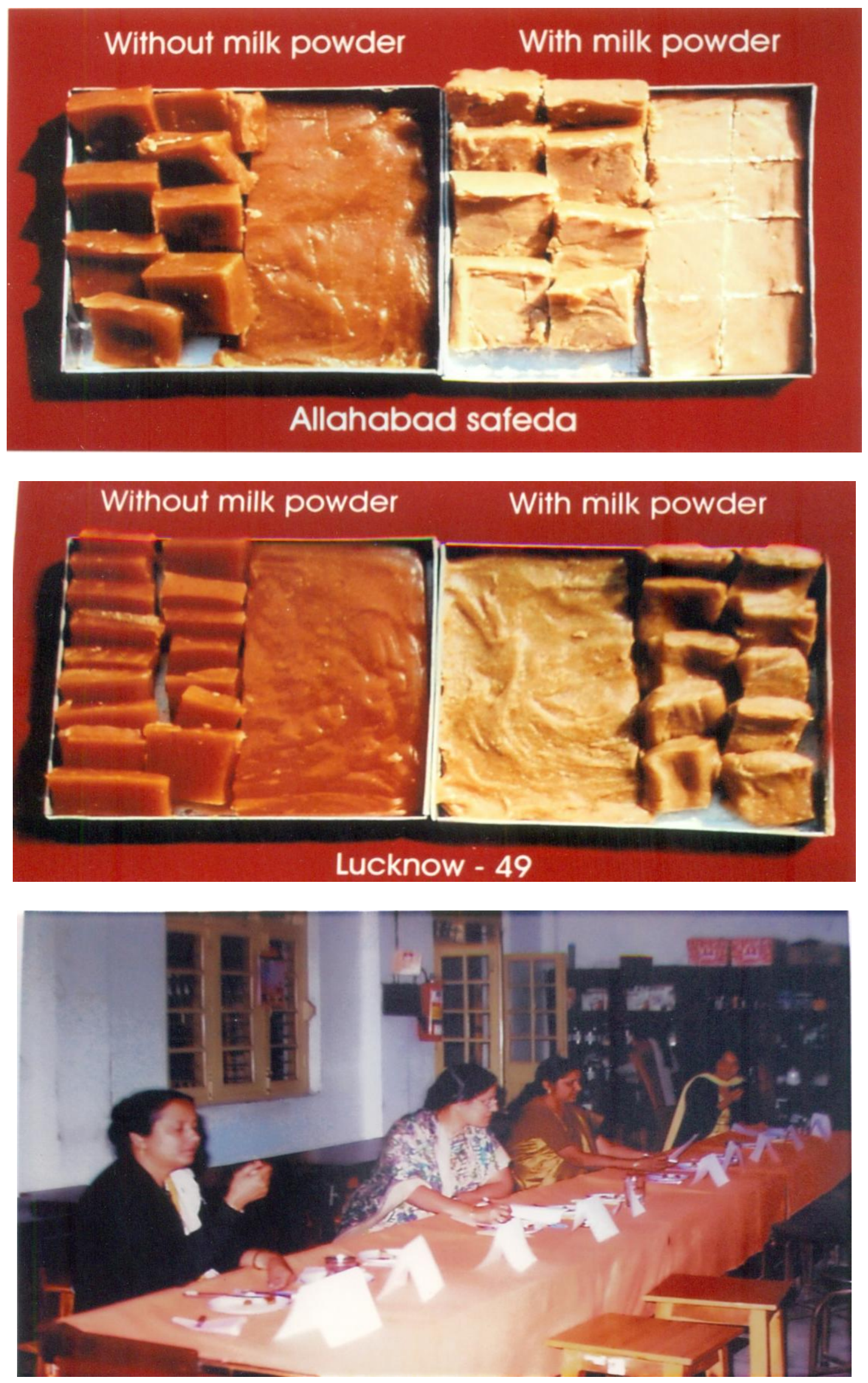


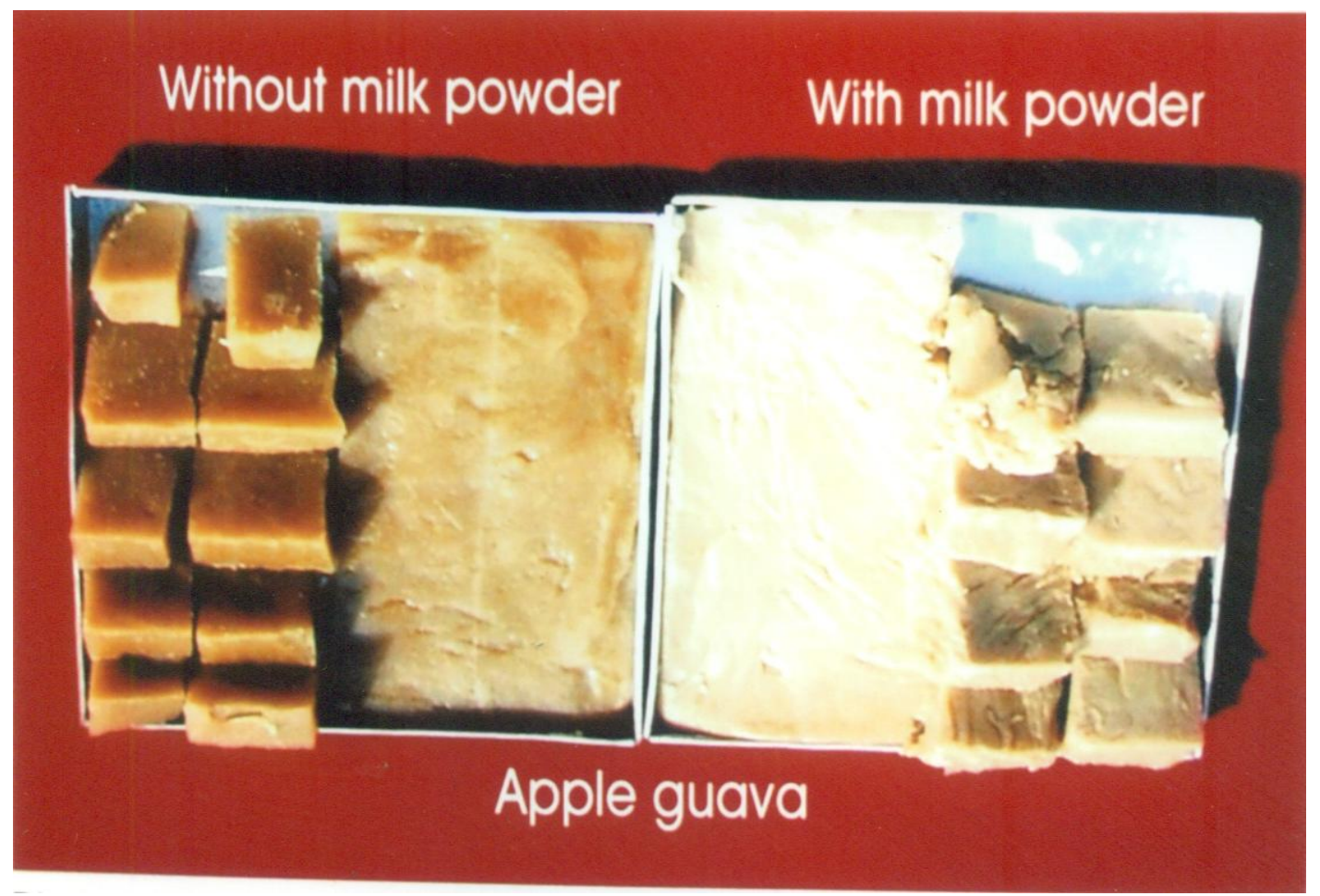

Table.1 Sensory evaluation in colour/appearance score in guava cheese

\begin{tabular}{|l|c|c|c|}
\hline \multicolumn{1}{|c|}{ Variety } & $\begin{array}{c}\text { Without milk } \\
\text { powder }\end{array}$ & $\begin{array}{c}\text { With milk } \\
\text { powder }\end{array}$ & Mean \\
\hline Lucknow-49 & 8.06 & 7.15 & $\mathbf{7 . 6 0}$ \\
\hline Allahabad safeda & 6.95 & 6.39 & $\mathbf{6 . 6 7}$ \\
\hline Apple guava & 8.50 & 7.30 & $\mathbf{7 . 9 0}$ \\
\hline Mean & $\mathbf{7 . 8 3}$ & $\mathbf{6 . 9 4}$ & \\
\hline & Variety & Additives & $\begin{array}{c}\text { Variety } \mathbf{x} \\
\text { Additives }\end{array}$ \\
\hline SEm \pm & & & 0.21 \\
\hline CD & 0.15 & 0.13 & $\mathbf{0 . 6 3}$ \\
\hline
\end{tabular}

Table.2 Sensory evaluation in taste score in guava cheese

\begin{tabular}{|l|c|c|c|}
\hline Variety & $\begin{array}{c}\text { Without milk } \\
\text { powder }\end{array}$ & $\begin{array}{c}\text { With milk } \\
\text { powder }\end{array}$ & Mean \\
\hline Lucknow-49 & 8.60 & 8.00 & $\mathbf{8 . 3 0}$ \\
\hline Allahabad safeda & 7.90 & 7.60 & $\mathbf{7 . 7 5}$ \\
\hline Apple guava & 8.40 & 8.20 & $\mathbf{8 . 3 0}$ \\
\hline Mean & $\mathbf{8 . 3 0}$ & $\mathbf{7 . 9 3}$ & \\
\hline & Variety & Additives & $\begin{array}{c}\text { Variety } \mathbf{x} \\
\text { Additives }\end{array}$ \\
\hline SEm \pm & 0.19 & 0.16 & 0.27 \\
\hline CD $(\mathbf{5 \%})$ & $\mathbf{0 . 5 7}$ & $\mathbf{0 . 4 6}$ & NS \\
\hline
\end{tabular}


Table.3 Sensory evaluation in flavor score in guava cheese

\begin{tabular}{|l|c|c|c|}
\hline Variety & $\begin{array}{c}\text { Without milk } \\
\text { powder }\end{array}$ & $\begin{array}{c}\text { With milk } \\
\text { powder }\end{array}$ & Mean \\
\hline Lucknow-49 & 8.10 & 7.25 & $\mathbf{7 . 6 7}$ \\
\hline Allahabad safeda & 7.80 & 7.20 & $\mathbf{7 . 5 0}$ \\
\hline Apple guava & 8.50 & 7.50 & $\mathbf{8 . 0 0}$ \\
\hline Mean & $\begin{array}{c}\mathbf{8 . 1 3} \\
\text { Variety }\end{array}$ & $\begin{array}{c}\mathbf{7 . 3 1} \\
\text { Additives }\end{array}$ & $\begin{array}{c}\text { Variety } \mathbf{x} \\
\text { Additives }\end{array}$ \\
\hline S E $\mathbf{~ m} \pm$ & & & 0.13 \\
\hline CD $\mathbf{( 5 \% )}$ & 0.15 & $\mathbf{0 . 3 7}$ & $\mathbf{N S}$ \\
\hline & $\mathbf{0 . 4 5}$ & & \\
\hline
\end{tabular}

Table.4 Sensory evaluation in texture score of guava cheese

\begin{tabular}{|l|c|c|c|}
\hline Variety & $\begin{array}{c}\text { Without milk } \\
\text { powder }\end{array}$ & $\begin{array}{c}\text { With milk } \\
\text { powder }\end{array}$ & Mean \\
\hline Lucknow-49 & 8.55 & 6.50 & 7.52 \\
\hline Allahabad safeda & 7.20 & 6.90 & 7.05 \\
\hline Apple guava & 7.10 & 7.00 & 7.05 \\
\hline Mean & $\mathbf{7 . 6 1}$ & $\mathbf{6 . 8 0}$ & \\
\hline & Variety & Additives & $\begin{array}{c}\text { Variety } \mathbf{x} \\
\text { Additives }\end{array}$ \\
\hline SEm \pm & 0.14 & 0.13 & 0.23 \\
\hline CD $(\mathbf{5 \%})$ & $\mathbf{0 . 4 1}$ & $\mathbf{0 . 4 0}$ & $\mathbf{0 . 6 8}$ \\
\hline
\end{tabular}

Table.5 Sensory evaluation in overall acceptability score in guava cheese

\begin{tabular}{|l|c|c|c|}
\hline Variety & $\begin{array}{c}\text { Without milk } \\
\text { powder }\end{array}$ & $\begin{array}{c}\text { With milk } \\
\text { powder }\end{array}$ & Mean \\
\hline Lucknow-49 & 8.32 & 7.23 & $\mathbf{7 . 7 8}$ \\
\hline Allahabad safeda & 7.35 & 7.02 & $\mathbf{7 . 1 9}$ \\
\hline Apple guava & 8.12 & 7.50 & $\mathbf{7 . 8 1}$ \\
\hline Mean & $\mathbf{7 . 9 3}$ & $\mathbf{7 . 2 5}$ & \\
\hline & Variety & Additives & $\begin{array}{c}\text { Variety } \mathbf{x} \\
\text { Additives }\end{array}$ \\
\hline SEm \pm & 0.16 & 0.13 & 0.22 \\
\hline CD $(\mathbf{5 \% )}$ & $\mathbf{0 . 4 7}$ & $\mathbf{0 . 3 8}$ & $\mathbf{0 . 6 7}$ \\
\hline
\end{tabular}

Variety Lucknow-49 recorded the higher point values of 8.32 closely followed by Apple guava (8.12) and it proved superior over rest of the treatments. Thus, it is inferred that the variety Apple guava is better for the preparation of cheese in terms of acceptability. The addition of milk powder shows the decrease in store of colour, taste, flavor, texture and overall acceptability. The decrease in these parameters might be due to decrease in ascorbic acid content and simultaneously pectin degradation. These 
finding are in agreement with the findings of Jain and Asati (2004) and Paul et al., (2005).Imran et al., (2000) and Patil et al., (2009) reported that the guava pulp treated with $5 \%$ percent sugar obtained maximum score for colour and flavour The addition of sugar up to $5 \%$ enhanced ascorbic acid retention as well as overall acceptance as compared to pulp with 7.5 and $10 \%$ added sugar. Thus, from the above findings it could be concluded that the variety Lucknow-49 proved to be a better over others and use of milk is not proved beneficial in improving to quality of cheese with respect to texture. Similar findings were noted by Aruna et al., (1999), Babu et al., (2006) and Walkunde et al., (2009).

\section{Acknowledgment}

The authors are grateful to the Department of Food and Nutrition Government M.H. College of Home Science \& Science for women, Jabalpur for providing me technical assistance and facilities to execute this study.

\section{References}

Ahmad, I., Khan, R. and Mohammad, A. 2000. Effect of added sugar of various concentrations on the storage stability of guava pulp. Sarhad J. Agriculture, 16(1): 89-93

Amerine, M.A., Pangborn, R.M. and Rossler, E.B. 1965. Principal of sensory evaluation of food. Academic press, New York.

Aruna, K., Vimla, V., Dhanalakshmi, K. and Reddy Vinodini 1999. Physicochemical changes during storage of papaya fruit (Carica papaya L.) bar (Thandra). J. Food Sci. Technol., 36(5): 428-433

Babu, C., Ramasamy, D. and Dhanalakshmi, B. (2006. Storage study of milk and fruit based beverage. Tamilnadu Journal of Veterinary and Animal Science, 25: 178-185.

Badrie, N and Cary Anderson 2005. Physicochemical quality and consumer acceptance of guava wines. J. food science, 42(3): 223-226

Baramanray, A., Gupta, O.P. and Dhawan, S.S. 1996. Comparison of guava hybrids with commercial cultivars for making jelly. Haryana J. Hort. Sci., 24(2): 196204.

Bose, T.K., Mitra, S.K., Farooqui, A.A. and Sandhu, M.K. 1999. Tropical Horticulture, 1: 297.

DAC 2007. Department of Agriculture and Cooperation, Ministry of Agriculture, Govt. of India. Web: http://agricoop.nic.in/hort/hortrevo.5.ht $\mathrm{m}$.

Hisn-Chun Chen, Ming Jen Shen, Liyun Lin and Chung May Wu 2007. Nutritional composition and volatile compounds in guava (Fresh Produce), 1(2): 132-139.

Imran, H., Tariq Masud and Habib Ahmed Rathore 2000. Effect of coating and wrapping materials on the shelf life of Apple. Journal of food safety, 5:24-34.

Jain, P.K. and Asati, V.K. 2004. Evaluation of guava cultivars for pulp preparation. Journal of Food Science and Technology, 41(6): 684-686

Lal, G. Siddappa, G.S. and Tondon, G.L. 1998. Preservation of fruits and vegetables. ICAR, New Delhi.

Mishra, Haridwar and Chopra, C.S. 2006. Processing and storage studies on bael fruit products: Crush and jam. Beverage and Food World, pp. 44-45.

Patil, A.P., Chavan, K.D. and Bhosale, D.N. 2009. Influence of addition of guava pulp and sugar an sensory quality of guava yoghurt. Journal of Dairying Foods and Home Science, 28(2): 95100.

Paul, S.E., Mazumdar, D., Chakraborty, S., Jana, S.C., Sarkar, S., Ray, S.K. and 
Hasan, M.K. 2005. Studies on preparation and storage of guava jelly. $1^{\text {st }}$ International Guava Symposium, December, p. 111.

Prasad, R.N. and Mali, P.C. 2006. Changes on physico-chemical characteristics of ber jam during storage. Indian J. Hort., 63(1): 86-87.

Shukla, F.C., Sharma, A. and Singh, B. 2003. Studies on the development of beverages using fruit juice/pulp separated milk and reconstituted skim milk. International Journal of Dairy Technology, 56(4): 243-246.

Walkunde, T.R., Kamble, D.K. and Pawar, B.K. 2009. Sensory quality of yoghurt from cow milk by utilizing guava fruit. Asian Journal of Animal Science, 3(2): 99-102.

\section{How to cite this article:}

Rashmi Shukla, Y.K. Shukla and Smita Pathak. 2018. Sensory Evaluation of Guava Cheese Prepared from Different Varieties. Int.J.Curr.Microbiol.App.Sci. 7(02): 780-789.

doi: https://doi.org/10.20546/ijcmas.2018.702.099 